\title{
INVESTIGASI DESAIN ARSITEKTUR YANG TIDAK TERKONDISI BERBASIS METODE PARTISIPATIF
}

\author{
Rian Faisal Asqhor ${ }^{1}$, Yandi Andri Yatmo*2, Kristanti Dewi Paramita ${ }^{3}$ \\ Teknik Arsitektur Universitas Indonesia 1, 2,3 \\ E-mail: 1'Rasqhor@gmail.com, *2yandiay@eng.ui.ac.id, ${ }^{3}$ kristanti.dewi@ui.ac.id
}

\begin{abstract}
Abstrak_ Artikel ini menginvestigasi mengenai arsitektur yang tidak terkondisi, yakni desain dengan ruang dan elemen arsitektur yang hadir tanpa keteraturan dan tanpa perencanaan sebelumnya. Pelibatan masyarakat menciptakan potensi variasi dalam membangun ruang dan elemen arsitektur yang bersifat non-conformity (ketidaksesuaian), dan dengan demikian berfungsi memperkaya ruang urban yang terbentuk. Arsitektur tidak lagi berfokus hanya pada estetika sebagai bentuk akhir desain, namun menjadi bagian dari upaya untuk memberikan masyarakat ruang untuk bermanuver dalam merancang ruang urban yang adaptif. Artikel ini membahas lebih lanjut akan metode desain arsitektur yang tidak terkondisi melalui riset kajian (desk research) studi kasus arsitektur berbasis partisipasi pada restorasi Amiriya Complex, pengembangan Kali Code, dan rumah bagi komunitas tradisional di Puebla, Mexico. Analisis studi kasus ini memperlihatkan bagaimana partisipasi masyarakat mengubah fungsi ruang dan menekankan lokalitas material yang tidak terkondisi sehingga menciptakan identitas baru sebagai ruang urban. Pemahaman akan mekanisme terbentuknya desain arsitektur yang tidak terkondisi diharapkan mampu menginisiasi cabang ilmu arsitektur yang melihat arsitektur di luar keteraturan serta melihat kemungkinan masyarakat sebagai aktor uta ma dalam produksi ruang keseharian pada konteks urban.
\end{abstract}

Kata Kunci : Arsitektur yang Tidak Terkondisi; Non-Conformity; Partisipasi; Urban.

\begin{abstract}
This article investigates unconditional architecture, which is a form of design with space and architectural elements with disordered characters that arise in an unplanned way. Engagement with the community provides potential variation in developing space and architectural elements that value non-conformity, enriching the urban space. Architecture no longer focuses on aesthetics within the final form of the design but provides maneuvering opportunities for the community to develop an adaptive urban space. This article focuses on the design method of unconditional architecture through case studies of participatory architecture in Amiriya Complex restoration, Code river development, and Puebla traditional dwellings for the community in Mexico. The analysis of these case studies demonstrates how community participation changes function and emphasize material localities that are unconditioned that generate new urban identity. Understanding the mechanism of unconditioned architecture aims to expand architectural knowledge that values architecture beyond its orderliness, and highlights possibilities of the community as the main actor in the production of everyday urban space.
\end{abstract}

Keyword: Uncoditional Architecture; Non- Conformity; Paritipatoru; Urban.

${ }^{1}$ Teknik Arsitektur Universitas Indonesia

${ }^{2}$ Teknik Arsitektur Universitas Indonesia

${ }^{3}$ Teknik Arsitektur Universitas Indonesia 


\section{PENDAHULUAN}

Artikel ini berupaya memahami desain yang tidak terkondisi yang terbentuk dari metode desain arsitektur berbasis partisipatif masyarakat. Arsitektur yang tidak terkondisi hadir dari perubahan-perubahan yang terjadi dalam proses desain yang muncul akibat upaya masyarakat untuk beradaptasi pada isu tertentu pada konteks (Upton, 2002). Terjadi berbagai perubahan secara ekonomi maupun budaya yang mampu mengubah ruang-ruang arsitektur di dalam suatu konteks sepanjang waktu, sehingga diperlukan suatu manuver desain yang responsif mampu menciptakan kesinambungan dan berjalan secara sinergis terhadap perubahan tersebut.

Metode desain arsitektur berbasis partisipatif berpotensi bergerak sinergis terhadap perubahan yang terjadi di masyarakat, karena masyarakat menjadi aktor utama dalam proses desain yang mampu bergerak bebas secara responsif dalam konteks (Upton, 2002: 723). Respons masyarakat ini menjadi bagian penting dalam mekanisme desain yang tidak terkondisi. Arsitektur yang tidak terkondisi berpotensi menciptakan desain yang adaptif dalam menjawab isu-isu yang terjadi di masyarakat, sehingga dapat memperkaya hadirnya arsitektur dalam suatu konteks.

Arsitektur yang tidak terkondisi merupakan bagian dari arsitektur yang terbentuk dari ketidaksesuaian (non-conformity). Tulisan ini mengangkat kualitas non-conforming dalam desain berdasarkan pembahasan Cousins (1995) akan konsep ugly dalam arsitektur, yang akan dijelaskan lebih lanjut dalam bagian kajian literatur. Ketidaksesuaian dapat hadir dengan proses merancang yang tidak terkondisi, terutama dengan pelibatan masyarakat yang membuka munculnya variasi yang tidak direncanakan dalam proses desain. Seberapa besar partisipasi masyarakat dalam berkontribusi menciptakan ruang memungkinkan ragam arsitektur yang tidak terkondisi itu hadir. Sherry (1969) dan Jones et al. (2005) mengemukakan bahwa tingkat citizen control menjadi bentuk parameter seberapa besar masyarakat dalam berkontribusi dan mendominasi proses desain memungkinkan hadirnya desain yang tidak terkondisi itu. Berdasarkan Arstein (1969) dan Upton (2002) arsitektur tidak terbatas dari guidelines yang ditentukan oleh desainer namun hadir dari hubungan antara masyarakat dan ruang yang terkait. Tulisan ini berupaya memahami bagaimana desain yang tidak terkondisi dapat menciptakan ruang arsitektur yang bersifat adaptif dan bagaimana mekanisme arsitektur yang tidak terkondisi hadir dalam proses desain yang berbasis partisipatif. Tulisan ini mengkaji pemahaman desain yang tidak terkondisi dan bagaimana partisipasi masyarakat membentuk desain yang tidak terkondisi tersebut, serta membahas penerapannya dalam studi kasus desain ruang publik dalam konteks urban.

\section{Memahami Desain yang Tidak Terkondisi Dalam Arsitektur}

Desain yang tidak terkondisi merupakan bentuk kontradiksi fungsi dari desain eksisting. Artinya, desain mengalami perubahan fungsi yang tidak semestinya hadir. Namun posisi yang tidak terkondisi ini bukan menjadi aspek yang dihindari karena dengan melihat ini menjadi penting. Pandangan desain tidak terbatas terhadap fungsi yang spesifik tetapi juga fungsi desain yang mampu adaptif dan bermanuver di dalam kebutuhan yang berubah-ubah, di luar kondisi yang ditetapkan di awal. Karakteristik desain yang tidak terkondisi sebenarnya ditentukan oleh seberapa adaptif desain itu hadir (Schuler, 1993 : 54). Berdasarkan Schuler (1993) dan Upton (2002) desain menjadi adaptif ketika desainer melihat perubahan kebutuhan di masa yang akan datang, sehingga desain yang dicapai dapat bersifat multifungsi dan menyesuaikan kebutuhan. Manuver desainer dalam melihat perubahan tersebut akan mempengaruhi form suatu desain. 
Dominasi masyarakat dalam proses merancang menjadi penting untuk berkontribusi menghadirkan form arsitektur yang tidak terkondisi (Arstein, 1993).

Kualitas form yang tidak terkondisi dibahas dalam pembahasan ugliness (Cousins, 1995) dalam arsitektur. Ugly merupakan suatu bentuk non-conformity dimana terdapat suatu stigma yang mengakibatkan suatu bentuk tidak diterima dan tidak sesuai dalam desain yang hanya berparameter estetika (Cousins, 1995). Akan tetapi terdapat beberapa pandangan yang mengkritik bahwa desain yang estetik membentuk fungsi yang ter simplifikasi (Cousins, 1998). Desain yang estetika membatasi fungsi yang dibutuhkan pengguna. Estetika tidak lagi menjadi kriteria penting dalam menghasilkan desain bila tidak menciptakan fungsi yang tepat sasaran. Dengan demikian, secara subjek, ugly dapat menjadi sesuatu yang diterima dan mampu menyesuaikan dalam desain, apabila ugly berpotensi mengedepankan fungsi tepat sasaran dalam ruang arsitektur melalui metode desain. Dengan demikian, sebuah arsitektur yang tidak terkondisi menjadi penting ketika ia menciptakan sesuatu fungsi yang tepat sasaran dan sesuai dengan kebutuhan penggunanya.

Ugly mampu menciptakan variasi bentuk dan konfigurasi dalam desain. Artinya variasi dalam ruang arsitektur diharapkan bersifat universal dan mampu diterima oleh masyarakat dan desainer. Berdasarkan Cousins (1995) dan Aspa (2021), variasi pada respon terhadap isu menciptakan bahasa-bahasa baru terkait bentuk dan fungsi sehingga posisi estetika yang bersifat rigid dan terbatas pada order mengalami pergeseran menjadi bentuk yang lebih fleksibel dan terbuka. Metode partisipasi memiliki potensi dalam membentuk variasi tersebut sebagai desain yang tidak terkondisi, karena ditentukan oleh tingkat kontribusi masyarakat dalam menciptakan ruang arsitektur yang tidak ditentukan di awal oleh desainer. Metode partisipasi berimbas pada hasil desain yang tidak terkondisi. Metode partisipasi berbeda dengan metode desain lain dimana desainer mendominasi proses perancangan. Metode yang tidak terkondisi dipengaruhi oleh terbatasnya dominasi desainer dengan kliennya, yang memungkinkan masyarakat untuk dapat bermanuver maupun berkolaborasi dengan desainer membentuk integrasi dalam proses perancangan.

Penekanan pada kontribusi masyarakat yang mendominasi dapat membuka peluang terjadinya sistem yang tidak terkondisi. Berdasarkan Cousins (1995) dan Gospodini (2001), sistem ini hadir karena tidak adanya pihak desainer dalam membatasi pergerakan masyarakat dalam mendesain. Pada arsitektur berbasis partisipasi, terdapat transformasi peran desainer. Desainer tidak lagi hadir sebagai praktisi ahli yang mengedepankan estetika dan terlepas dari kebutuhan keseharian, namun sebagai perantara yang memahami kebutuhan dan pengetahuan pengguna da $\mathrm{n}$ memberikan ruang untuk kebutuhan dan pengetahuan tersebut untuk berkembang (Till, 2005). Di sisi lain, pengguna memiliki peran untuk mentransformasikan pengetahuan arsitektur itu sendiri melalui potensi respon dan intervensi yang dikembangkan. Hasil dari arsitektur partisipatif di masa sekarang memperlihatkan pergeseran posisi estetika dari sebagai suatu yang diutamakan sebagai hasil akhir semata hingga menjadi sesuatu yang menumbuhkan kualitas yang penting bagi pengguna dalam merespon dan mengintervensi desain. Realita kebutuhan individu dalam tiap waktunya bersifat dinamis, artinya desain tidak bekerja secara adaptif dalam menyesuaikan kebutuhan pengguna setiap waktu. Dengan hal itu, akhirnya respon dari pengguna membentuk suatu perubahan fungsi dari eksisting desain sehingga menghasilkan desain yang tidak terkondisi (lihat Gambar 1). 


\begin{tabular}{lll}
$\begin{array}{c}\text { Consultation Participatory } \\
\text { Conditional Design }\end{array}$ & & $\begin{array}{c}\text { Citizen Control } \\
\text { Unconditional Design }\end{array}$ \\
\hline Architect and Client & Time $\quad$ More Needs for Human Being & Not Fit in Design
\end{tabular}

Gambar 1. Unconditional Design Hadir dari Adaptasi Masyarakat Pada Suatu Desain Yang Dibentuk Oleh Arsitek Dan Klien Di Masa Lampau Sumber : Ilustrasi penulis

Berdasarkan Finn (1998) dan Aspa (2001), desainer kerap tidak menghasilkan desain yang mampu menyesuaikan kebutuhan pengguna di masa yang akan datang sehingga adanya variabel fungsi yang hilang pada proses riset desain. Konsekuensi dari ketidaksesuaian fungsi tersebut kemudian adalah hadirnya respon dari pengguna dalam menyikapi eksisting desain yang sudah terbentuk dan tidak menyesuaikan form yang ditentukan. Desain yang tidak terkondisi dengan demikian hadir dari proses penyesuaian tersebut. Dalam prosesnya, form yang hadir dalam proses penambahan dari eksisting form dapat menciptakan pengaruh visual pengguna yang akan dibahas lebih lanjut dalam paragraf berikut.

\section{Perubahan Form pada Arsitektur Tidak Terkondisi Terkait Dengan Proses Partisipasi}

Arsitektur berbasis partisipasi memahami proses produksi ruang berbasis transformasi peran pengguna (Jones, Petrescu, and Till, 2005). Kehadiran partisipasi dalam proses desain mengubah tidak hanya peran pengguna namun juga praktik arsitektur secara keseluruhan (Till, 2005). Proses partisipasi dalam arsitektur mulai dikenal pada tahun 1960 an seiring dengan adanya perubahan tatanan sosial di masyarakat Barat sebagai bagian dari upaya mencapai masyarakat yang lebih setara dan melawan kecenderungan deterministik pada desain (Albrecht, 1988). Proses partisipasi memberikan peran terhadap kaum yang kerap dianggap minoritas dan tidak direpresentasikan dalam cerminan sosial dan politik perkotaan untuk memiliki andil dalam proses perencanaan (Till, 2005; Opazo, Wolff, Araya, 2017). Pengembangan desain yang hadir dari masyarakat merupakan bentuk adaptasi terhadap konteks isu tertentu sehingga membentuk mekanisme yang tidak terkondisi (Arstein 1969: 33). Berdasarkan Arstein (1969) dan Aspa (2001), dalam proses arsitektur berbasis partisipasi terdapat berbagai tahapan partisipasi yang terkait dengan seberapa besar kontribusi desainer dan masyarakat dalam menciptakan ruang publik. Dalam proses perancangan arsitektur berbasis partisipasi, desainer menghasilkan variabel bebas dan terikat sebagai bentuk batasan terhadap masyarakat dalam berpartisipasi. Variabel bebas tersebut terkait dengan bagaimana desainer menciptakan ruang sisa dari desain yang secara tidak langsung adanya pertimbangan dari masyarakat dalam menciptakan ruangnya sendiri (Aspa, 2001). Di sisi lain, variabel terikat terkait dengan batasan yang dihadirkan oleh desainer agar desain yang diciptakan tidak terlepas dari konsep yang ditetapkan pada kedua belah pihak.

Diagram A Ladder of Citizen Participation yang dikemukakan oleh Arstein (1969) (lihat Gambar 2) mengulas berbagai tingkatan partisipasi yang memperlihatkan keterlibatan warga dalam penerapan dan penentuan kebijakan dan perencanaan dalam konteks perkotaan. Dalam kaitannya dengan ranah perancangan arsitektur, diagram ini kemudian menjadi basis untuk merefleksikan kemungkinan perancangan yang dikembangkan oleh suatu komunitas berbasis 
pengetahuan yang mereka sendiri miliki untuk kesesuaian suatu desain (Till, 2005). Citizen control merupakan tingkatan yang didominasi oleh masyarakat dalam menghasilkan suatu keputusan dan pengorganisasian secara mandiri (Arstein, 1969). Dalam konteks arsitektur, tingkatan Citizen control merupakan posisi dimana masyarakat menjadi desainer dalam menciptakan ruang yang diinginkan. Citizen control merupakan bentuk partisipasi yang dikoordinasi oleh masyarakat itu sendiri secara sepihak. Hal ini berpotensi menjadikan bentuk yang sama sekali tidak dibatasi oleh desainer sebagai advisor. Tahapan citizen control sebagai dalam arsitektur yang partisipasi dengan demikian berpotensi menciptakan desain tidak terkondisi. Masyarakat menciptakan desain yang merespon desain eksisting dan membentuk konfigurasi form baru yang tersintesis melalui eksplorasi yang terjadi dan dengan demikian hadir sebagai bentuk desain yang adaptif.

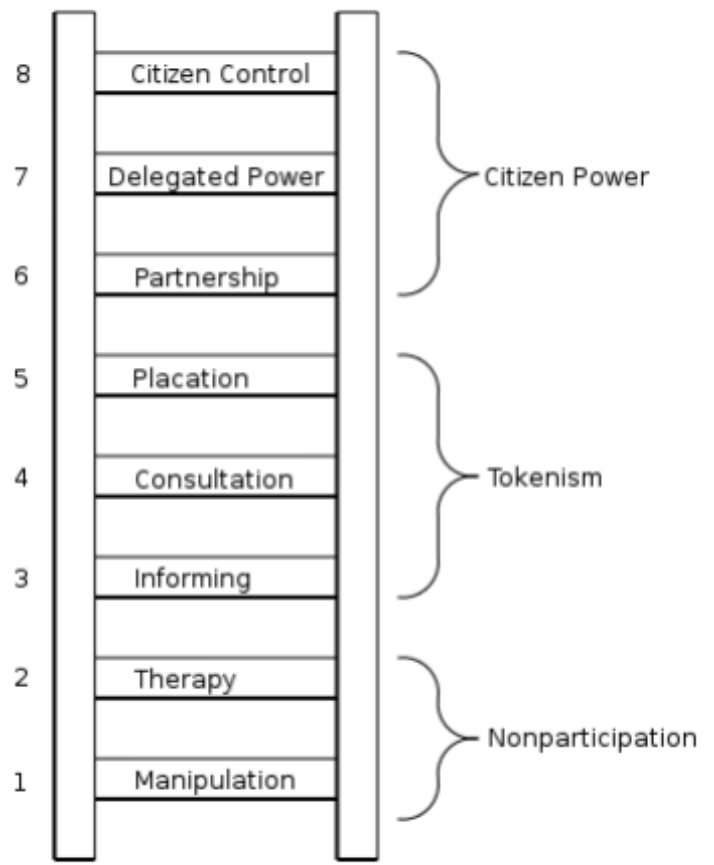

Gambar 2. Citizen Control Hadir Setelah Terjadinya Tipe Participatory yang Bersifat Tokenism Sumber : A Ladder of Citizen Participation (1969), p. 2

Terkait dengan form sebagai variabel yang bermanuver di dalam metode desain partisipatif, pembahasan ini kemudian membuka posisi penting bagaimana form terbentuk dalam arsitektur yang tidak terkondisi melalui repetisi dan eksplorasi form untuk menghindari misfitpr. Misfit bentuk dari ketidaksesuaian fungsi form terhadap konteks isu. Misfit hadir karena tidak adanya repetisi dan eksplorasi form untuk menciptakan desain yang adaptif (Alexander, 1964). Membaca keseharian pengguna menjadi penting untuk menghindari terjadinya misfit dalam desain. Berdasarkan Arstein (1969) dan Alexander (1964), navigasi merupakan sub tahapan di dalam metode arsitektur partisipatif yang mampu menciptakan analisis yang komprehensif untuk menghindari terjadinya misfit. Menurut pendapat penulis, navigasi bekerja sinergis untuk menjembatani antara desainer dan klien untuk menciptakan penyelesaian kebutuhan di dalam proses desain. Terkait dengan membaca ruang urban, navigasi merupakan suatu cara yang dapat melihat secara luas dari beberapa aspek pendukung baik secara mikro (personal) maupun makro. Potensi variasi ruang urban merupakan sesuatu yang mampu dibaca melalui proses navigasi. 
Navigasi bergerak bebas di dalam pembentukan form sebagai jawaban dalam membaca konteks. Artinya navigasi membuka posibilitas bagaimana desainer mengeksplorasi dan merepetisi form yang ada sehingga membentuk form yang lebih kompleks. Repetisi dan eksplorasi sebagai bagian dari navigasi dalam menyikapi konteks sehingga dapat mempertimbangkan form apa yang sesuai sebagai bentuk jawaban desain. Terkait dengan repetisi dan mengeksplorasi form, proses ini didahului oleh bagaimana statement yang ditentukan sudah melewati kesepakatan antara klien dan desainer. Kemudian menciptakan skenario apa yang terjadi di dalam suatu konteks (Finn, 1998). Serta klien menghadirkan aspirasi dari apa yang mereka inginkan namun tetap menghadirkan batasan-batasan yang ditentukan oleh desainer.

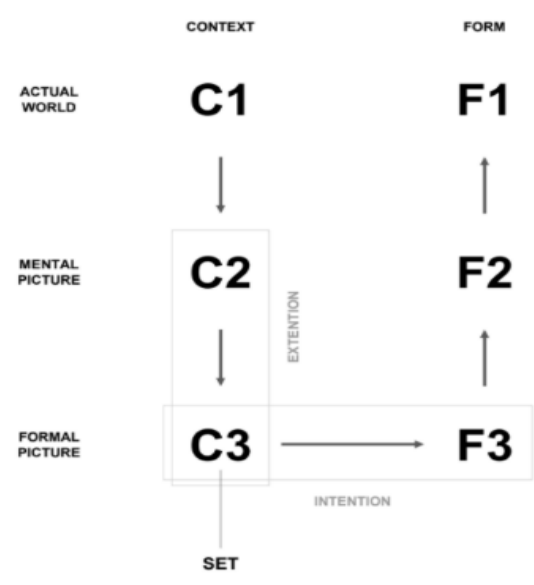

Gambar 3. Skema Synthesis of Form Yang Menjelaskan Bagaimana Navigasi Mengarahkan Konteks ke Form Sebagai Bentuk Evaluasi Dari Desain Sumber : Diadaptasi dari buku Synthesis of form, p. 35

Dalam proses arsitektur berbasis partisipasi, navigasi mempengaruhi proses repetisi dan eksplorasi form yang memungkinkan peran antar individu dan komunitas untuk menciptakan ruangnya sendiri. Gambar 3 juga menjelaskan bahwa fase F3-F1 merupakan sekuensi perubahan form. Sudut pandang desainer dalam mempertimbangkan desain berbasis participatory adalah dengan melihat kebutuhan dari pengguna. Berdasarkan Finn (1998) dan Aspa (2001)), kebutuhan tersebut menjadi bentuk yang mampu dinavigasi oleh desainer dalam menyikapi desainnya, namun di sisi lain memberikan wadah klien sebagai partisipan dalam menciptakan desain.

Navigasi hadir di dalam tidak terkoneksinya metode desain berbasis partisipatif. Bagaimana pada akhirnya konteks terkait dengan masyarakat dalam menciptakan form dibutuhkan. Masyarakat melakukan navigasi agar fungsi dapat tepat sasaran sehingga sesuai kebutuhan dan menghindari terjadinya misfit dalam form. Pembahasan selanjutnya lebih terfokus terhadap metodologi pembahasan studi kasus akan arsitektur yang tidak terkondisi yang hadir di dalam intervensi ruang urban yang berbasis partisipasi. Studi kasus ini membongkar esensi apa saja yang bisa didapat dalam mempelajari tiap ruang arsitektur yang tidak terkondisi dan bagaimana kualitas tersebut memperkaya ruang urban.

\section{METODOLOGI PENELITIAN}

Studi kasus arsitektur yang tidak terkondisi berupaya memahami bagaimana masyarakat menyikapi konteks yang ada melalui lokalitas yang terjadi, serta merespon stigma pembentukan 
ruang yang rigid dan order tidak selamanya hadir dan mencapai fungsi tepat sasaran. Pendekatan studi kasus sebagai metode riset pada artikel ini menjadi relevan untuk menginvestigasi suatu fenomena kontekstual yang nyata (Groat dan Wang, 2013). Pendekatan studi kasus dalam riset umumnya memiliki berbagai variabel yang menjadi basis observasi dan berlandaskan suatu paradigma teori yang telah dibangun sebelumnya (Yin, 2003). Pendekatan studi kasus memungkinkan terjadinya generalisasi terhadap hubungan-hubungan antar variabel yang terbangun untuk memastikan validitas dan ketepatan hasil riset (Groat dan Wang, 2013). Studi kasus dalam artikel ini mengangkat proyek restorasi Amiriya Complex, intervensi perkampungan Kali Code, serta arsitektur residensial untuk komunitas tradisional di Puebla, Mexico Ketiga proyek ini merupakan bentuk arsitektur berbasis partisipasi yang memiliki tingkat partisipatif citizen control (Arnstein, 1969) yang begitu besar dalam mengubah alih fungsi ruang arsitektur. Melalui ketiga proyek tersebut, arsitektur yang tidak terkondisi mampu mengubah zonasi ruang yang bersifat privat menjadi publik. Masyarakat yang tidak terkondisi dalam membentuk ruangnya mampu menghasilkan desain yang adaptif dan fungsi yang tepat sasaran, serta memberikan identitas baru terhadap suatu kawasan urban. Arsitektur yang tidak terkondisi pada konteks lingkungan yang cenderung rentan seperti kawasan rawan bencana mengharuskan masyarakat mengeksplorasi material dan form sebagai bentuk jawaban suatu kondisi yang fluktuatif.

Studi kasus ini memanfaatkan kajian literatur dari berbagai sumber untuk membaca mekanisme hadirnya arsitektur yang tidak terkondisi yang memiliki kualitas ketidaksesuaian (nonconformity) namun sebenarnya mampu menciptakan fungsi desain yang adaptif. Mekanisme tersebut memperlihatkan bagaimana masyarakat sebagai aktor yang mampu menciptakan ruang sehingga membentuk desain yang tepat sasaran. Fleksibilitas dan keterbukaan di dalam metode yang tidak terkondisi menjadi bentuk yang non-conforming tidak perlu dihindari dan justru memiliki posisi penting di dalam arsitektur partisipatif.

\section{Memahami Arsitektur yang Tidak Terkondisi: Studi Kasus Restorasi Ruang Urban Berbasis Partisipasi}

\section{A. Restorasi Amiriya Complex}

Pada proyek restorasi Amiriya Complex, bangunan tersebut diintervensi dengan mekanisme partisipatif berbasis citizen control. Fungsi bangunan awal merupakan bangunan ibadah dan madrasah yang dibangun oleh 'desainer Abd Al-Wahab pada abad 1980. Pada masanya desainer melakukan metode tokenism, yaitu tingkatan partisipatif dimana desainer hadir sebagai advisor terhadap pengguna. Hasil yang terbentuk menciptakan ruang zonasi yang bersifat privat yang di kemudian hari kemudian membentuk isu baru terkait dengan kebutuhan madrasah sebagai institusi akademik yang bersifat publik.

Pada masa sekarang akhirnya bangunan ini direstorasi oleh pemerintah dari aspirasi masyarakat untuk menghasilkan bangunan serbaguna dalam menyediakan event dan bazar. Dalam proses restorasinya, masyarakat dilibatkan untuk turut mendesain ruang melalui ukiran serta lokalitas material sehingga menciptakan ruang publik yang bervariasi dan beridentitas. Dapat terlihat secara visual bahwa ukiran satu dengan lainnya tidak menciptakan senada dan harmonis (Gambar 4). karena tidak adanya batasan dari pihak desainer dan tidak terkondisinya masyrakat dalam menciptakan ruang. Akan tetapi, setiap ruang memberikan 
ambience berbeda dan dengan demikian turut menciptakan zonasi yang tepat sebagai suatu ruang publik.

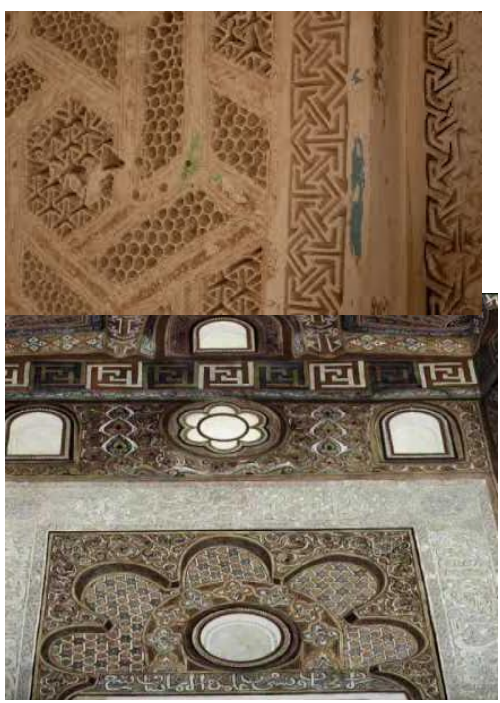

Gambar 4. Restorasi Amiriya yang menghasilkan berbagai ukiran lokal sebagai bentuk partisipasi yang disepakati oleh pemerintah dari aspirasi masyarakat.

Sumber: https://archnet.org/sites/4169

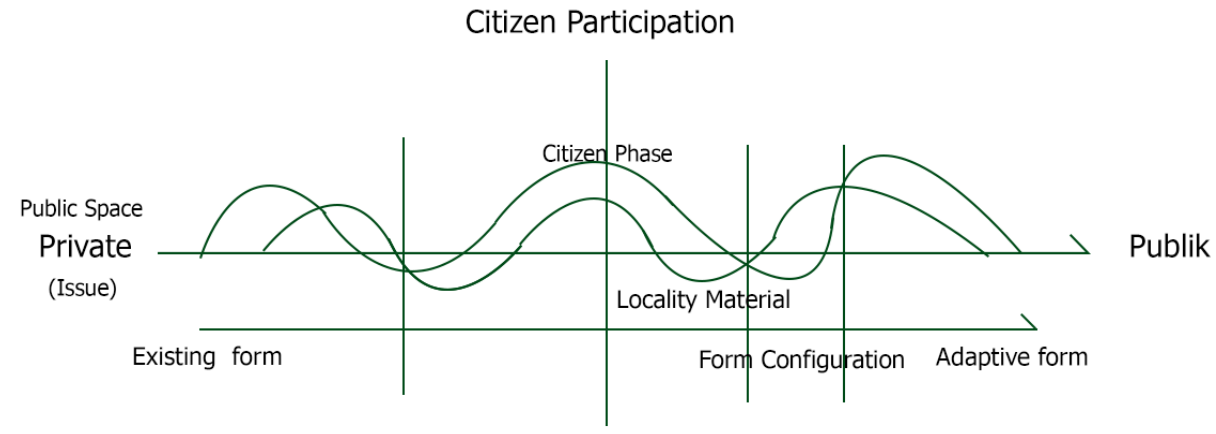

Participatory Architecture

Gambar 5. Mekanisme Bagaimana Citizen Control Menciptakan Desain Melalui Lokalitas Material Serta Konfigurasi Ukiran Sebagai Pembentuk Zona Publik. Sumber: Ilustrasi Penulis

Diagram pada Gambar 5 menjelaskan mekanisme perubahan pembentukan ruang terkait dengan tingkatan kontribusi masyarakat dan desainer dalam konteks restorasi Amiriya Complex. Di awal proses metode didominasi oleh desainer sebagai bentuk advisor. Namun saat proses realisasi itu terjadi, posisi desainer tergantikan oleh pihak masyarakat sebagai aktor utama dalam menciptakan ruang arsitektur. Mekanisme dalam mengubah fungsi ruang Amiriya Complex berkaitan dengan mekanisme partisipasi masyarakat dalam proses perancangan. Pembentukan form yang adaptive (Mark (1998) diawali dengan melihat potensi di dalam existing form, serta melihat potensi apa yang terjadi bila adanya komponen lain (extending form) di dalam existing. Form yang berkembang menciptakan variabel fungsi lain untuk menjawab kebutuhan yang baru.

Di proses transisi pembentukan form adaptif, masyarakat menciptakan eksplorasi form melalui proses trial dan error. Trial dan error merupakan bentuk tidak terkondisinya 
mekanisme metode rancang, karena masyarakat tidak melihat bagaimana metode tersebut terbentuk secara kesatuan, namun mengubah-ubah dan memberikan variasi terhadap kualitas visual ruang. Namun, tidak terkondisinya tersebut justru menghasilkan eksplorasi akan identitas visual ruang, yang dimana prosesnya menciptakan desain yang mampu menjawab kebutuhan akan ruang publik secara baik.

\section{B. Restorasi Perkampungan Kali Code}

Proyek restorasi perkampungan Kali Code lebih menekankan pada resistensi terhadap ruang urban yang cenderung rigid dan memberikan efek samping terhadap kesenjangan sosial. Ruang urban yang terbentuk secara rigid cenderung mengedepankan estetika namun belum tentu menghasilkan fungsi yang tepat sasaran. Menyikapi isu tersebut masyarakat mencoba membentuk identitas baru di perkampungannya sebagai area yang mampu menekankan fungsi objek wisata pada ruang kota Yogyakarta. Desainer dan masyarakat mencoba merestorasi ruang urban, mengikuti landasan arsitektur partisipatif berbasis citizen control. Masyarakat menjadi aktor utama serta desainer berperan sebagai advisor untuk mencapai fungsi yang tepat sasaran. Restorasi ini mengangkat konsep kebebasan dalam bertempat tinggal menjadi bentuk perlawanan rigidity dan order dari pembentukan ruang publik. Perlawanan tersebut hadir melalui konfigurasi warna fasad sebagai ekspresi lokalitas dan identitas masyarakat perkampungan Kali Code.
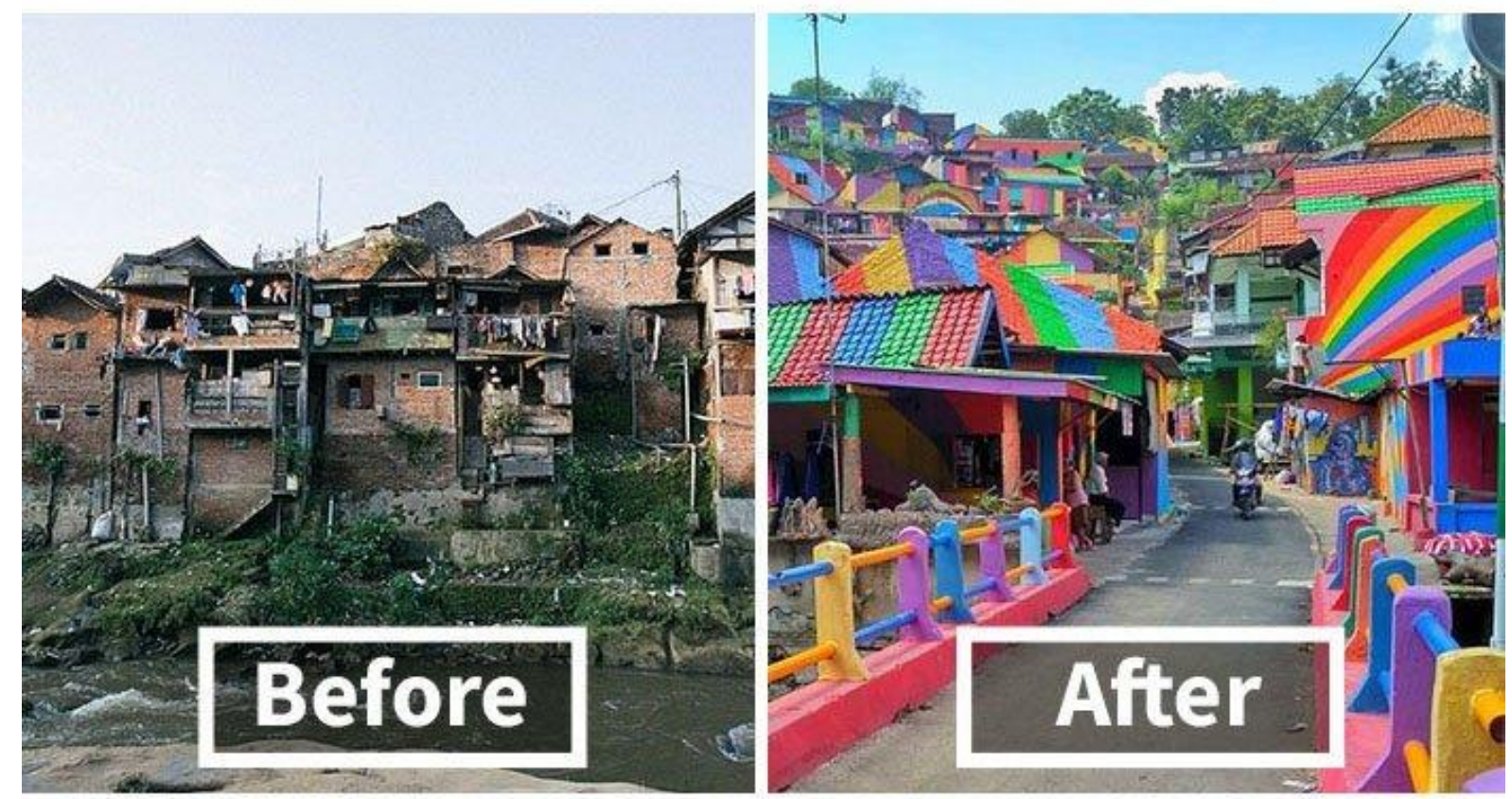

Gambar 6. Restorasi Perkampungan Kali Code dengan menggunakan partisipasi masyarakat sebagai perlawanan pembentukan ruang urban yang bersifat kaku dan teratur. Sumber: http://www.arsitekturindonesiada.org/ 


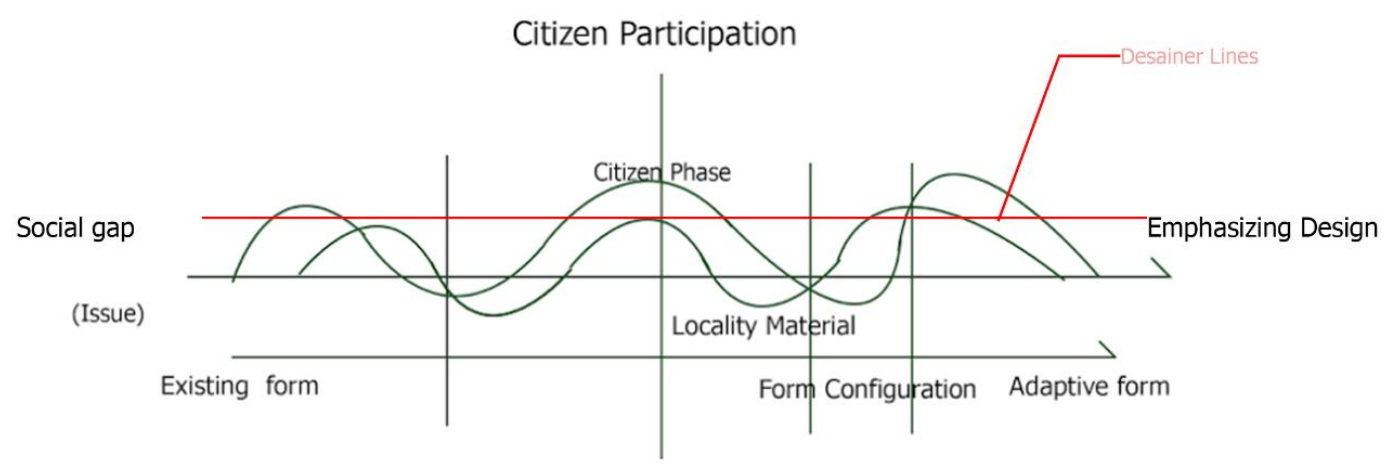

Participatory Architecture

Gambar 7. Mekanisme keterhubungan antara citizen dan desainer sebagai bentuk partisipatif pada proyek restorasi perkampungan Kali Code, posisi desainer sebagai observant pada proses masyarakat dalam menciptakan desain. Sumber: Ilustrasi penulis

Diagram mekanisme restorasi perkampungan Kali Code pada Gambar 7 memperlihatkan tahapan bagaimana desainer berkontribusi di dalam proses intervensi yang diciptakan oleh masyarakat tersebut. Warna sebagai identitas merupakan bentuk aspirasi yang diinginkan oleh masyarakat agar menciptakan desain yang memberikan penekanan (emphasizing) terhadap ruang bertinggal urban tersebut. Tetapi hal yang ditekankan disini adalah adanya pergerakan desainer bersifat linier, yang memperlihatkan bagaimana di akhir proses desain, desainer melakukan observasi bagaimana masyarakat bermetode dan menciptakan desainnya. Esensi pada proses perancangan yang dihasilkan oleh masyarakat kemudian diintegrasikan oleh desainer dalam menghasilkan arsitektur yang tidak terkondisi namun menjawab kebutuhan yang diinginkan.

\section{Rural House, Puebla}

Contoh studi kasus selanjutnya terjadi pada proyek rumah di wilayah Puebla yang menekankan pada bangunan yang menurunkan suhu ruang. Studi kasus terkait dengan literatur mengenai masyarakat mencoba mengubah alih fungsi desain yang tidak semestinya dipergunakan, menjadi sesuatu yang lebih bermanfaat. Disini saya melihat bahwa citizen control begitu luas dalam melihat posibilitas yang terjadi pada fungsi material dan form desain yang sebenarnya. Konfigurasi material dan form teradaptasi sehingga menciptakan fungsi yang tepat sasaran. Dari pembahasan studi kasus ini masyarakat secara unselfconscious mampu mengkonfigurasi beberapa existing form dan lokalitas material di lingkungannya sehingga menciptakan konfigurasi baru yang lebih kompleks fungsinya. Fungsi yang kompleks membuka peluang bahwa masyarakat memiliki kontribusi penting dalam menciptakan metode desain yang komprehensif namun tidak terbatas pada suatu batasan yang rigid dan ordered.

Gambar 9 menjelaskan bagaimana keadaan lingkungan rumah menciptakan penurunan suhu dari panas yang ekstrim di dalam lingkungan Puebla. Suhu panas yang ekstrim merupakan bentuk isu yang diselesaikan melalui penggunaan material yang ditentukan oleh ketebalan material untuk menciptakan bangunan mereduksi suhu panas. Namun di kondisi tertentu Puebla merupakan wilayah yang rawan akan gempa sehingga masyarakat berupaya 
mengkonfigurasi ulang material yang dengan tidak melayer material untuk menciptakan massa yang ringan struktur yang fleksibel dan mampu adaptif dalam situasi gempa. Pengguna berupaya mengkonfigurasi ulang material dengan sistem layer untuk merespon isu apa yang terjadi dalam lingkungan, baik terkait dengan kondisi suhu ekstrim maupun kondisi wilayah Puebla yang rawan akan gempa.

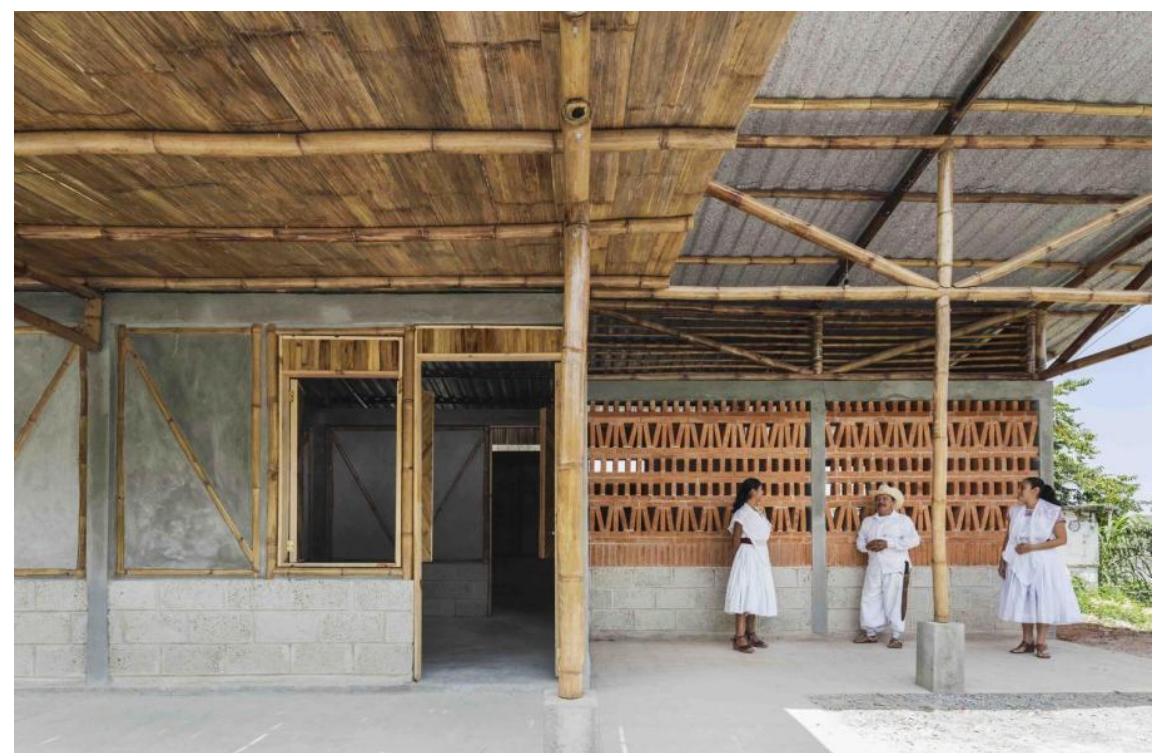

Gambar 9. Konfigurasi material sebagai bentuk arsitektur yang tidak terkondisi dalam menciptakan lingkungan yang terkondisi secara suhu dan kondisi gempa

Sumber: https://www.archdaily.com/868726/vivienda-en-puebla

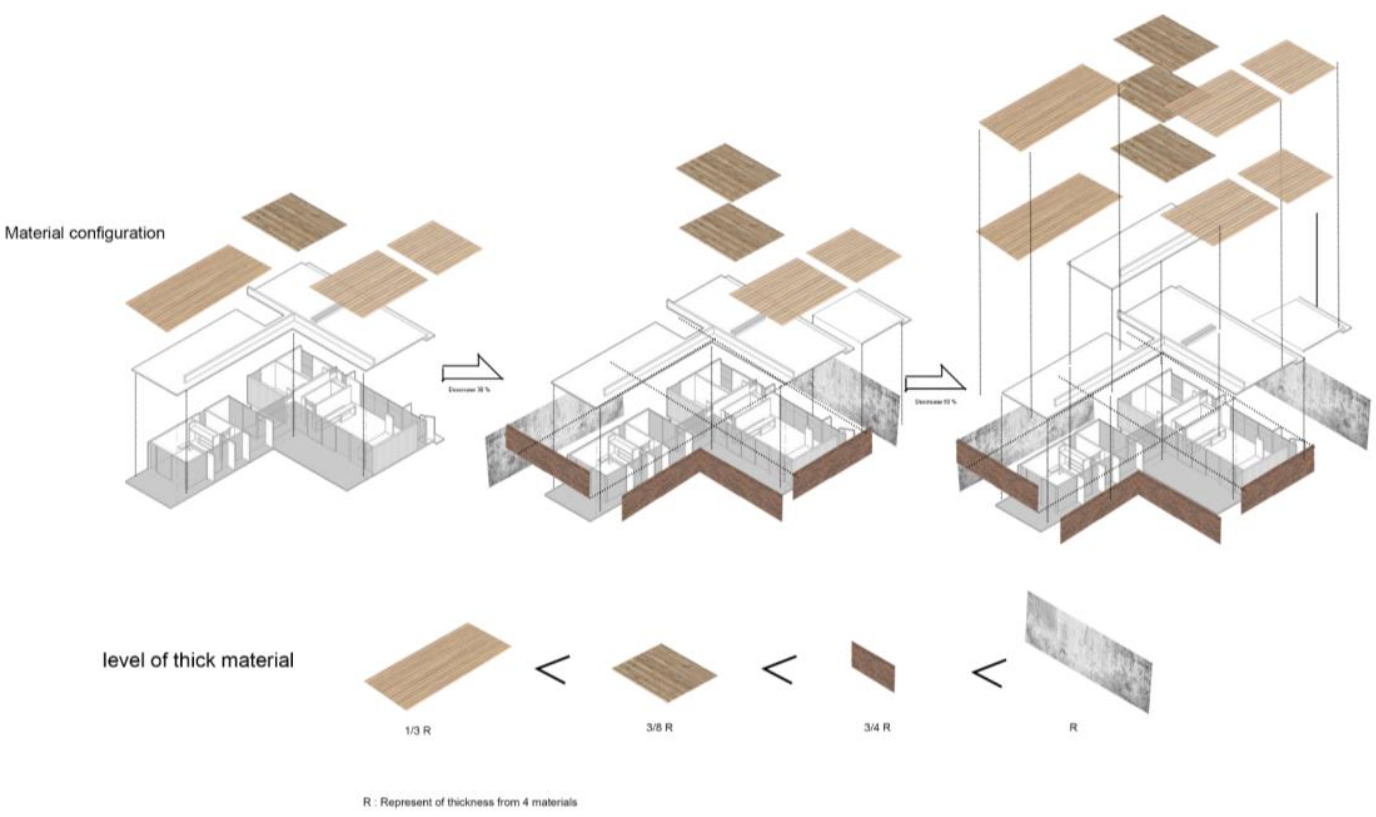

Gambar 9. Material yang ada menciptakan ruang yang adaptif terhadap suhu ekstrim serta menghasilkan perluasan ruang pada setiap sisi. Sumber: Ilustrasi penulis 
Dari pembahasan literatur dan studi kasus, saya menemukan bahwa tidak terkoneksinya desain di dalam metode partisipatif arsitektur berpotensi mencapai fungsi yang adaptif melalui upaya masyarakat dalam menciptakan ruang. Masyarakat merespon isu yang ada dengan mengeksplorasi dan merepetisi form dan material eksisting sehingga hasil dari desain bersifat trial dan error. Berdasarkan hasil eksplorasi tersebut, masyarakat kemudian menformasi ulang hingga di tahap form tersebut menjadi adaptif dalam menjawab kebutuhan masyarakat yang baru. Tahapan desain non rigid menjadi titik penting bagaimana mekanisme tidak terkondisi itu terbentuk. Dari literatur terkait, sintesis form terbentuk melalui eksploratif non-rigid yang diciptakan oleh masyarakat (citizen control) yang tidak memiliki pengkondisian sebelumnya. Dalam proses arsitektur yang tidak terkondisi, desainer berperan dalam menyikapi skenario yang ada serta strategi yang dihasilkan dari partisipasi masyarakat untuk mencapai kualitas non-conforming namun mencapai fungsi yang diinginkan.

\section{Mekanisme Spasial Arsitektur Yang Tidak Terkondisi Berbasis Partisipasi}

Berdasarkan studi kasus, pembahasan pada bagian ini memetakan bagaimana mekanisme arsitektur yang tidak terkondisi itu hadir dari masyarakat sebagai perancang. Pemetaan ini memahami bagaimana mekanisme yang tidak terkondisi hadir dengan kualitas yang bersifat nonconforming yang muncul dari proses yang dilakukan masyarakat dalam menciptakan formasi yang non-rigid dalam metode desainnya. Terkait dengan desain yang tidak terkondisi, masyarakat menciptakan extending form dalam membuat ruang yang dibutuhkan. Tahapan metode yang hadir dapat dilihat pada diagram berikut.

\section{CITIZEN CONTROL PARTICIPATION}

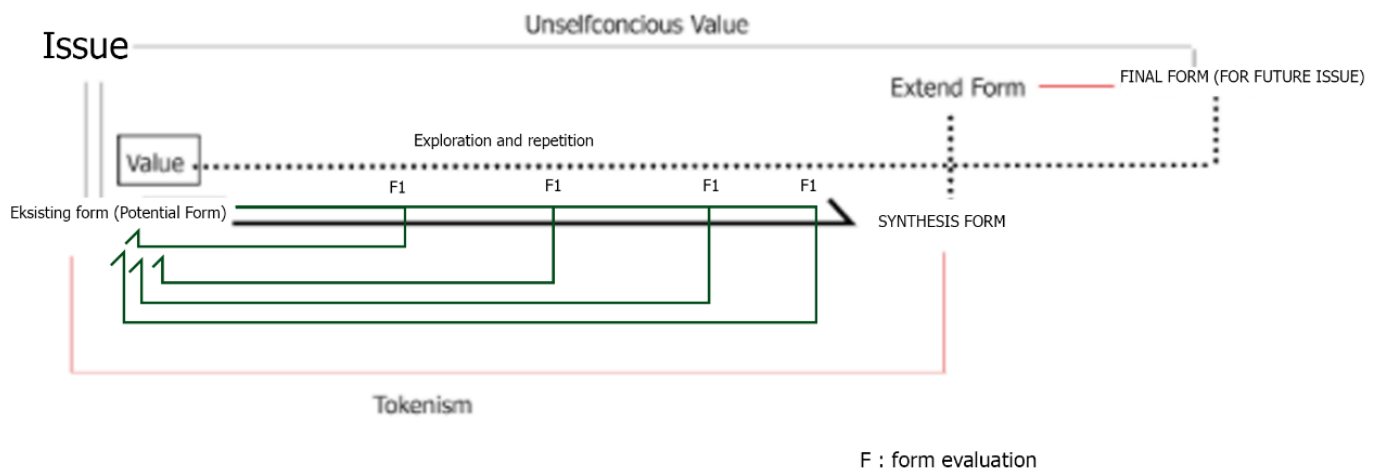

Gambar 10. Mekanisme masyarakat yang tidak terkondisi dengan mengkonfigurasi eksisting form hingga pada tahapan form yang teradaptasi

Sumber: Ilustrasi penulis

Skema pada Gambar 10 merupakan gambaran besar bagaimana mekanisme spasial arsitektur yang tidak terkondisikan terbentuk oleh partisipasi masyarakat dalam proses perancangan. Masyarakat bermanuver di dalam pengembangan form dari bentuk eksistingnya dan menciptakan kemungkinan desain untuk mengalami formasi bentuk yang adaptif. Dari tahapan ini, kita bisa menemukan bahwa mekanisme spasial arsitektur yang tidak terkondisi sebenarnya mampu berkontribusi besar dalam menjawab isu tertentu, melalui tahapan-tahapan berikut: 


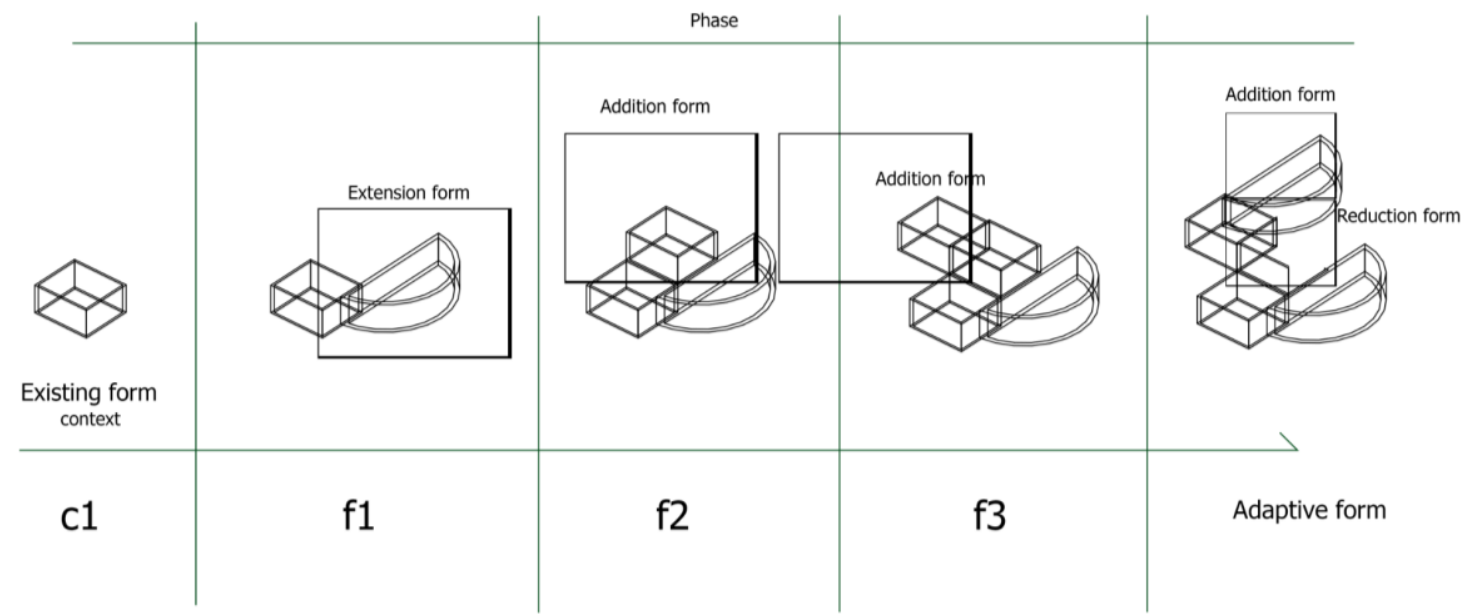

Gambar 11. Pembentukan form dari tahapan eksisting yang mengalami ekstensi dari form lain dan reduksi untuk menghindari terjadinya misfit

Sumber: Ilustrasi penulis

$\rightarrow$ Navigating: Pada tahapan ini, masyarakat melihat konteks untuk menemukan isu serta kebutuhan apa saja yang hadir. Dari isu tersebut, masyarakat diharapkan mampu merespon dan merevitalisasi kembali ruang yang ada sehingga mampu menjawab isu di dalam konteks. Dalam tahapan revitalisasi tersebut tidak selalu terjadi sintesis form sebagai bagian sekuensi pembentukan desain. Revitalisasi dalam tahap ini tidak selamanya mampu menyelesaikan isu didalam karena sifatnya hanya mampu menyelesaikan isu yang bersifat mikro dan tidak mencapai eksplorasi terhadap form suatu arsitektur.

$\rightarrow$ Exploration and reversed: Pada tahapan ini, masyarakat sudah mampu mengeksplorasi form untuk menciptakan sintesis form. Pergerakan masyarakat pada tahapan ini bersifat trial dan error artinya terdapat upaya untuk menemukan form yang ideal serta mengulang kembali bila form yang dihasilkan masih bersifat misfit. Proses reversed diartikan bahwa masyarakat merekonfigurasi setiap variabel form yang berpotensi menciptakan misfit sehingga proses dalam membentuk sintesis form tidak bersifat linier.

$\rightarrow$ Extension: Tahap ini merupakan tahapan akhir masyarakat mengembangkan antar sintesis form yang dihasilkan sehingga menciptakan final form yang utuh. Hasil pengembangan (extension) diharapkan membentuk form yang adaptif yang merespon terhadap perubahan isu di masyarakat dan kebutuhannya yang terkait. Sebagaimana karakter extension form, ketidakkonsistenan masyarakat dalam membentuk form menjadi suatu variabel bebas yang sebenarnya mampu dikonfigurasi ulang bila konteks yang ada mengalami perubahan isu.

\section{KESIMPULAN}

Tulisan ini menginvestigasi arsitektur yang tidak terkondisi yang hadir dari partisipasi masyarakat dalam proses perancangan. Berdasarkan diskursus ugliness, arsitektur yang tidak terkondisi merupakan arsitektur yang memiliki kualitas non-conformity atau ketidakkonsistenan akibat tidak adanya pengkondisian oleh desainer dalam proses perancangan. Melalui 
ketidakkonsistenan dalam proses perancangan, masyarakat bergerak bebas dengan mengeksplorasi form yang dibentuknya dan menciptakan sistem trial dan error. Arsitektur yang tidak terkondisi menjadi penting bagi masyarakat untuk menciptakan desain yang adaptif dan sesuai dengan perubahan kondisi dan kebutuhan masyarakat. Arsitektur yang tidak terkondisi namun bersifat adaptif diharapkan mampu mengubah stigma tidak terkoneksinya desain, bukan hanya sebagai sesuatu yang dihindari. Form arsitektur tidak terkondisi yang dikembangkan melalui proses navigating, repetitive exploration dan extension, memperlihatkan kontribusi masyarakat dalam menciptakan ruangnya sendiri, dan dengan demikian memperkaya kualitas ruang urban yang hadir.

\section{DAFTAR REFERENSI}

Albrecht, J. (1988). Towards a Theory of Participation in Architecture: An Examination of Humanistic Planning Theories. Journal of Architectural Education (1984-), 42(1), 24-31. https://doi.org/10.2307/1424997

Alexander, C. (1964). Notes on the Synthesis of Form (Vol. 5). Harvard University Press.

Amiriya Restoration (Aga Khan Award for Architecture, 2007) https://archnet.org/sites/4916

Arnstein, Sherry R. "A Ladder of Citizen Participation," JAIP, Vol. 35, No. 4, July 1969, pp. 216-224

Jones, P. B., Petrescu, D., \& Till, J. (Eds.). (2005). Architecture and Participation. Routledge.

Cousins, Mark. "THE UGLY [Part 1]." AA Files, no. 28, 1994, pp. 61-64. JSTOR, www.jstor.org/stable/29543923. Accessed 11 Jan. 2021.

Cousins, Mark. "THE UGLY [Part 2]." AA Files, no. 29, 1995, pp. 3-6. JSTOR, www.jstor.org/stable/29543944. Accessed 11 Jan. 2021.

Cousins, Mark. "THE UGLY [Part 3]." AA Files, no. 30, 1995, pp. 12-20. JSTOR, www.jstor.org/stable/29543944. Accessed 11 Jan. 2021.

Finn Kensing, Jesper Simonsen \& Keld Bodker (1998) MUST: A Method for Participatory Design, HumanComputer Interaction, 13:2, 167-198, DOI: 10.1207/s15327051hci1302_3

Gospodini, Aspa (2001) Urban Design, Urban Space Morphology, Urban Tourism: An Emerging New Paradigm Concerning Their Relationship, European Planning Studies, 9:7, 925-934, DOI: $10.1080 / 09654310120079841$

Groat, L. N., \& Wang, D. (2013). Architectural Research Methods. John Wiley and Sons.

Guimera, Roger, and Marta Sales-Pardo. "Form follows function: the architecture of complex networks. no. 1 (2006): 42.

Opazo, D., Wolff, M., \& Araya, M. J. (2017). Imagination and the Political in Design Participation. Design Issues, 33(4), 73-82. https://doi.org/10.1162/DESI_a_00462

Schuler, Douglas. (1993). Participatory Design: Principles and Practices. London: Lawrence Erlblaum Associates, pp. 41-79.

Till, Jeremy and Wigglesworth, Sarah, eds. (1998) The Everyday and Architecture. Architectural design profile (134). Academy Editions, London.

Till, J. (2005). The Negotiation of Hope. In P. B. Jones, D. Petrescu, \& J. Till (Eds.), Architecture and Participation. Spon Press.

Upton, D. (2002). Architecture in Everyday Life. New Literary History, 33(4), 707-723. Retrieved January 11, 2021, from http://www.jstor.org/stable/20057752

Wigglesworth, Sarah and Till, Jeremy (1998) Table manners. In: Wigglesworth, Sarah and Till, Jeremy, (eds.) The everyday and architecture. London, U.K. : Architectural Design. pp. 31-35. (Architectural Design Profile, (134)) ISSN (print) 0003-8504 ISBN 0471984248

Yin, R. K. (2017). Case Study Research and Applications: Design and Methods (6th edition). SAGE Publications, Inc. 